\title{
Helobdella blinni sp. n. (Hirudinida, Glossiphoniidae) a new species inhabiting Montezuma Well, Arizona, USA
}

\author{
Rebecca K. Beresic-Perrins', Fredric R. Govedich², Kelsey Banister', \\ Bonnie A. Bain², Devin Rose', Stephen M. Shuster'
}

I Department of Biological Sciences, Northern Arizona University, 617 S. Beaver St., PO Box 5640 Flagstaff, AZ, 86011-5640 2 Department of Biological Sciences, Southern Utah University, 351 W. University Blvd. Cedar City, UT, 84720

Corresponding author: Fredric R. Govedich (govedich@suu.edu)

Academic editor: S. James | Received 30 June 2016 | Accepted 1 March 2017 | Published 15 March 2017

http://zoobank.org/963C2520-3C29-419B-A5D1-0518E9713DD5

Citation: Beresic-Perrins RK, Govedich FR, Banister K, Bain BA, Rose D, Shuster SM (2017) Helobdella blinni sp. n. (Hirudinida, Glossiphoniidae) a new species inhabiting Montezuma Well, Arizona, USA. ZooKeys 661: 137-155. https://doi.org/10.3897/zookeys.661.9728

\begin{abstract}
A new leech species Helobdella blinni sp. n., is described from Montezuma Well, an isolated travertine spring mound located in central Arizona, USA. In its native habitat, H. blinni had been previously identified as Helobdella stagnalis (Linnaeus, 1758), which was later reclassified to Helobdella modesta (Verrill, 1872). Similar to the European H. stagnalis and North American H. modesta, H. blinni has six pairs of testisacs, five pairs of smooth crop caecae, one lobed pair of posteriorly-directed crop caecae, one pair of eyes, a nuchal scute, and diffuse salivary glands. However, the pigmentation of this new species ranges from light to dark brown, unlike $H$. modesta which tends to be light grey in color. Also, H. modesta produces a clutch of 12--35 pink eggs, whereas $H$. blinni produces smaller clutches of white eggs (7-14, $0.5 \pm 0.15 \mathrm{~mm}, \mathrm{~N}=7)$ and consequently broods fewer young $(1-14,7 \pm 3.3 \mathrm{~mm}, \mathrm{~N}=97)$. Helobdella blinni are also able to breed year-round due to the constant warm water conditions in Montezuma Well. Their breeding season is not restricted by seasonal temperatures. These species are morphologically similar, however, comparing the COI mtDNA sequences of $H$. blinni with sequences from nearby populations of H. modesta and other Helobdella species from GenBank indicate that $H$. blinni is genetically distinct from these other Helobdella populations.
\end{abstract}

\section{Keywords}

Leech, Glossiphoniidae, Helobdella blinni sp. n., new species, Montezuma Well

Copyright Rebecca K. Beresic-Perrins et al. This is an open access article distributed under the terms of the Creative Commons Attribution License (CC BY 4.0), which permits unrestricted use, distribution, and reproduction in any medium, provided the original author and source are credited. 


\section{Introduction}

Montezuma Well is a collapsed travertine spring mound located $72 \mathrm{~km}$ south of Flagstaff in the Verde Valley of Northern Arizona $\left(34.6491^{\circ} \mathrm{N}, 111.7522^{\circ} \mathrm{W}\right.$ (DD)) (Fig. 1A). The age of Montezuma Well is estimated to be $-11,000$ years (Wagner and Blinn 1987). This location is thermally constant year-round $\left(19-24^{\circ} \mathrm{C}\right)$ and is continuously replenished by two vents located at the well bottom. Montezuma Well is 0.76 ha in area and approximately $20 \mathrm{~m}$ deep. Most of the shoreline drops off immediately into open water, except at the northeast corner where water drains through a shallow region called the "swallet" and empties into Wet Beaver Creek which is located east of Montezuma Well (Fig. 1A-B). The water within Montezuma Well has unique water chemistry, containing high levels of arsenic $(>100 \mu \mathrm{g} / \mathrm{L})$ and dissolved $\mathrm{CO}_{2}(>300 \mathrm{mg} / \mathrm{L})($ Cole and Barry 1973).

Four leech species are known to inhabit Montezuma Well, including an endemic pelagic predator (Govedich et al. 1998), the erpobdellid Motobdella montezuma (Davies et al. 1985), and three other glossiphoniid species currently identified as Helobdella papillata (Moore, 1952), H. elongata (Castle, 1900), and a species currently thought to be H. stagnalis (Linnaeus, 1758), all of which inhabit the swallet (Fig. 1B). These Montezuma Well leech populations are thought to have been isolated from other leech populations for as long as 11,000 years (Wagner and Blinn 1987).

In support of this hypothesis, Beresic-Perrins's (2010) description of brood size, parental behavior, and life history of the Montezuma Well population of H. stagnalis suggests that this leech is distinct from other known populations of $H$. stagnalis, a species originally described from Europe and which had until very recently been considered to be a widespread cosmopolitan leech species, inhabiting both Europe and North America. Siddall et al. (2005) addressed this problem by resurrecting the original species description for the North American leech, Helobdella modesta (Verrill, 1872) which had long been considered to be a synonym of the European H. stagnalis (Moore 1898). The molecular analysis by Moser et al. (2011) provided confirmation for the resurrection of $H$. modesta by Siddall et al. (2005). Even though the two species are morphologically indistinguishable (Verrill 1872, Moore 1898, Moore 1952), they differ genetically. Henceforth, we will refer to the North American H. stagnalis as $H$. modesta.

Here, we compare key traits, both morphological and molecular, among members of the Montezuma Well Helobdella sp. population, several other nearby populations of H. modesta, and several other Helobdella species. Our molecular analysis includes the cytochrome $c$ oxidase subunit I (COI) mitochondrial gene region to test the hypothesis that the Montezuma Well population of $H$. modesta is a distinct species and warrants a new species description. This region is known to be sufficiently variable to reveal interspecific differences and unlikely to suggest differences due to elevated mutation rates (Apakupakul et al. 1999). 

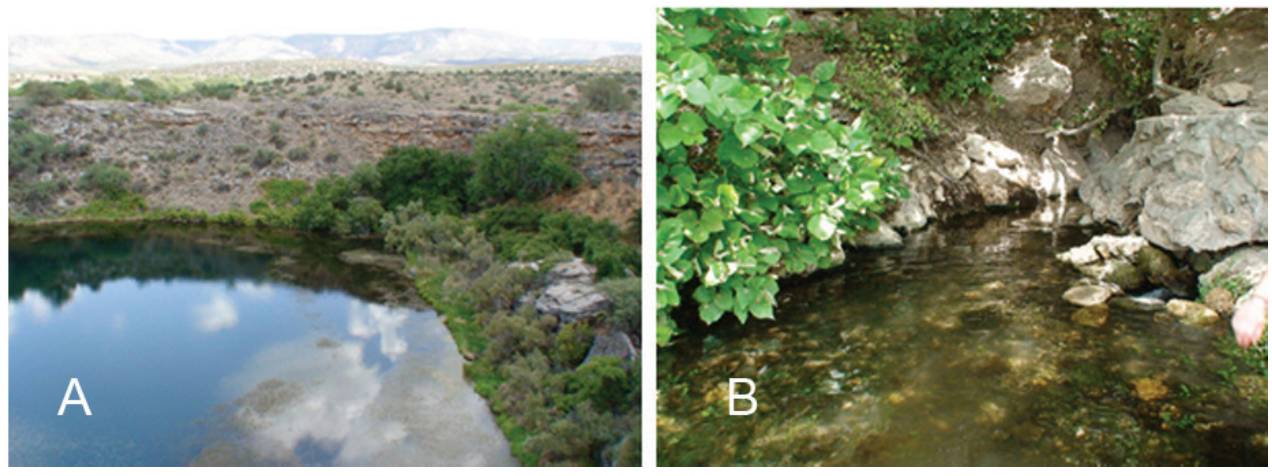

Figure I. Location of Helobdella blinni sp. n. A The northeast side of Montezuma Well; and B The swallet where the leeches were collected.

\section{Materials and methods}

\section{Sampling}

A total of 34 individuals of Helobdella sp. inhabiting Montezuma Well were collected from the underside of rocks in the swallet: five specimens were collected in June 2011 for molecular analysis and 29 were collected in June 2012 to assess morphological characteristics. For the molecular analysis, the leeches were preserved in $95 \%$ ethanol and others, for museum collections, were fixed with buffered formalin overnight and preserved in $70 \%$ ethanol. Additionally, a total of 10 specimens of $H$. c.f. modesta from Rio de Flag ponds near the Rio de Flag Waste Water Facility outflow in Flagstaff, Arizona $\left(35.18418^{\circ} \mathrm{N}, 111.63294^{\circ} \mathrm{W}(\mathrm{DD})\right)$ and Oak Creek, AZ near the Cave Springs campground $\left(34.9961^{\circ} \mathrm{N}, 111.7394^{\circ} \mathrm{W}(\mathrm{DD})\right)$ were collected for molecular analyses. These specimens were also fixed in $95 \%$ ethanol.

\section{Morphological examination}

We documented number of eyes and their placement, color pattern, presence of papillae, number of and structure of gastric caecae, body size, presence of nuchal scute, gonopore placement, egg size and number, and number of offspring using a Nikon binocular dissecting microscope. We then deposited the examined materials in the Invertebrate Zoology collection at the Smithsonian Institution, National Museum of Natural History (USNM).

\section{Molecular analysis}

Whole DNA was extracted from the caudal suckers of the individual leeches using a Qiagen DNeasy Blood \& Tissue Kit (Cat. No. 69504), with each sample incubated 
Table I. Helobdella and outgroup taxa used for our molecular analysis.

\begin{tabular}{|c|c|c|}
\hline Taxon & Locality & Reference \\
\hline Cystobranchus salmositicus & Outgroup & Williams and Burreson 2006 \\
\hline Ozobranchus margoi & Outgroup & Siddall and Burreson 1998 \\
\hline Gonimosobdella klemmi & Outgroup & Williams and Burreson 2005 \\
\hline Myzobdella lugubris & Outgroup & Siddall and Burreson 1998 \\
\hline Helobdella atli & French Guiana & Oceguera-Figueroa et al. 2010 \\
\hline Helobdella atli & Uruguay & Oceguera-Figueroa et al. 2010 \\
\hline Helobdella atli & Mexico & Oceguera-Figueroa et al. 2010 \\
\hline Helobdella blinni sp. $\mathrm{n}$. & Montezuma Well, AZ, USA & This study \\
\hline Helobdella blinni sp. $\mathrm{n}$. & Montezuma Well, AZ, USA & This study \\
\hline Helobdella blinni sp. $\mathrm{n}$. & Montezuma Well, AZ, USA & This study \\
\hline Helobdella bolivianita & Bolivia & Siddall and Borda 2002 \\
\hline Helobdella bowermani & Oregon, USA & Moser et al. 2013 \\
\hline Helobdella bowermani & Oregon, USA & Moser et al. 2013 \\
\hline Helobdella bowermani & Oregon, USA & Moser et al. 2013 \\
\hline Helobdella californica & California, USA & Kutschera 2011 \\
\hline Helobdella "elongata" & Mexico & Oceguera-Figueroa et al. 2010 \\
\hline Helobdella europaea & Taiwan & Lai et al. 2009 \\
\hline Helobdella europaea & Taiwan & Lai et al. 2009 \\
\hline Helobdella europaea & Taiwan & Lai et al. 2009 \\
\hline Helobdella europaea & Taiwan & Lai et al. 2009 \\
\hline Helobdella europaea & South Africa & Siddall and Budinoff 2005 \\
\hline Helobdella lineata & Michigan, USA & Siddall and Borda 2002 \\
\hline Helobdella fusca & Michigan, USA & Siddall and Borda 2002 \\
\hline Helobdella melananus & Taiwan & Lai et al. 2009 \\
\hline Helobdella melananus & Taiwan & Lai et al. 2009 \\
\hline Helobdella melananus & Taiwan & Lai et al. 2009 \\
\hline Helobdella michaelseni & Chile & Siddall and Borda 2002 \\
\hline Helobdella modesta & Columbus, Ohio, USA & Siddall and Borda 2002 \\
\hline Helobdella modesta & Washington, USA & Oceguera-Figueroa et al. 2010 \\
\hline Helobdella modesta & Washington, USA & Oceguera-Figueroa et al. 2010 \\
\hline Helobdella c.f. modesta & Rio de Flag, Flagstaff, AZ, USA & This study \\
\hline Helobdella c.f. modesta & Rio de Flag, Flagstaff, AZ, USA & This study \\
\hline Helobdella c.f. modesta & Oak Creek, AZ, USA & This study \\
\hline Helobdella c.f. modesta & Oak Creek, AZ, USA & This study \\
\hline Helobdella nununununojensis & Bolivia & Siddall and Borda 2002 \\
\hline Helobdella nununununojensis & Bolivia & Siddall and Borda 2002 \\
\hline Helobdella octatestisaca & Taiwan & Lai et al. 2009 \\
\hline Helobdella octatestisaca & Taiwan & Lai et al. 2009 \\
\hline Helobdella octatestisaca & Taiwan & Lai et al. 2009 \\
\hline Helobdella octatestisaca & Taiwan & Lai et al. 2009 \\
\hline Helobdella octatestisaca & Taiwan & Lai et al. 2009 \\
\hline Helobdella octatestisaca & Taiwan & Lai et al. 2009 \\
\hline Helobdella octatestisaca & Taiwan & Lai et al. 2009 \\
\hline Helobdella octatestisaca & South Africa & Oceguera-Figueroa et al. 2010 \\
\hline
\end{tabular}




\begin{tabular}{|c|c|c|}
\hline Taxon & Locality & Reference \\
\hline Helobdella octatestisaca & Mexico & Oceguera-Figueroa et al. 2010 \\
\hline Helobdella octatestisaca & Mexico & Oceguera-Figueroa et al. 2010 \\
\hline Helobdella octatestisaca & Mexico & Oceguera-Figueroa et al. 2010 \\
\hline Helobdella octatestisaca & Mexico & Oceguera-Figueroa et al. 2010 \\
\hline Helobdella octatestisaca & Mexico & Oceguera-Figueroa et al. 2010 \\
\hline Helobdella papillata & Michigan, USA & Siddall and Borda 2002 \\
\hline Helobdella papillata & Virginia, USA & Siddall and Borda 2002 \\
\hline Helobdella papillornata & Australia & Siddall and Borda 2002 \\
\hline Helobdella paranensis & Uruguay & Siddall and Borda 2002 \\
\hline Helobdella pichipanan & Bolivia & Siddall et al. 2005 \\
\hline Helobdella "robusta" TXAU1 & Texas, USA & Bely and Weisblat 2006 \\
\hline Helobdella "robusta" & California, USA & Bely and Weisblat 2006 \\
\hline Helobdella "robusta" CASA 1 & California, USA & Bely and Weisblat 2006 \\
\hline Helobdella "robusta" NYTA & New York, USA & Bely and Weisblat 2006 \\
\hline Helobdella simplex & Argentina & Moser et al. 2006 \\
\hline Helobdella simplex & Argentina & Moser et al. 2006 \\
\hline Helobdella simplex & Argentina & Moser et al. 2006 \\
\hline Helobdella socimulcensis & Mexico & Oceguera-Figueroa et al. 2010 \\
\hline Helobdella socimulcensis & Mexico & Oceguera-Figueroa et al. 2010 \\
\hline Helobdella socimulcensis & Mexico & Oceguera-Figueroa et al. 2010 \\
\hline Helobdella socimulcensis & Mexico & Oceguera-Figueroa et al. 2010 \\
\hline Helobdella socimulcensis & Mexico & Oceguera-Figueroa et al. 2010 \\
\hline Helobdella socimulcensis & Mexico & Oceguera-Figueroa et al. 2010 \\
\hline Helobdella socimulcensis & Mexico & Oceguera-Figueroa et al. 2010 \\
\hline Helobdella sp. Xochimilco & Mexico & Oceguera-Figueroa et al. 2010 \\
\hline Helobdella sorojchi & Bolivia & Siddall and Borda 2002 \\
\hline Helobdella sorojchi & Bolivia & Siddall and Borda 2002 \\
\hline Helobdella stagnalis & United Kingdom & Siddall and Borda 2002 \\
\hline Helobdella "stagnalis" & Mexico & Oceguera-Figueroa et al. 2010 \\
\hline Helobdella "stagnalis" & Mexico & Oceguera-Figueroa et al. 2010 \\
\hline Helobdella transversa & Michigan, USA & Siddall and Borda 2002 \\
\hline Helobdella triserialis & Bolivia & Siddall and Borda 2002 \\
\hline Helobdella triserialis & California, USA & Bely and Weisblat 2006 \\
\hline Helobdella virginiae & Mexico & Oceguera-Figueroa et al. 2010 \\
\hline
\end{tabular}

overnight in a water bath set at $54^{\circ} \mathrm{C}$. Using Siddall and Borda's (2002) PCR method, the mitochondrial gene region, cytochrome $c$ oxidase subunit I (COI) was amplified. The primers were LCO1490 5'-GGTCAACAAATCATAAAGATATTGG-3' and HCO2198 5'-TAAACTTCAGGGTGACCAAAAAATCA-3' (Folmer et al. 1994). The PCR product was purified through the use of the QIAquick PCR Purification Protocol (Cat. No. 28104), checked for PCR product using gel electrophoresis, and sequenced with an ABI Prism 3730 sequencer (Applied Biosystems). We imported the seven "cleanest" sequences and 71 comparative sequences (Table 1) from previous studies (Siddall and Burreson 1998, Siddall and Borda 2002, Siddall and Budinoff 
2005, Siddall et al. 2005, Williams and Burreson 2005, Bely and Weisblat 2006, Williams and Burreson 2006, Lai et al. 2009, Oceguera-Figueroa et al. 2010, Kutschera 2011, Moser et al. 2013) from GenBank (http://www.ncbi.nlm.nih.gov/genbank/) into MEGA7.0.18 (Kumar et al. 2016). We aligned the sequences automatically using MUSCLE (Edgar 2004) and then corrected the alignments by hand. We partitioned the data and performed the substitution model test by codon in Partitionfinder (Lanfear et al. 2012). The best substitution model test was General Time Reversal (GTR) +gamma which we used in our maximum-likelihood (ML) analysis (Lanave et al. 1984, Tavare 1986, Rodriguez et al. 1990). For ML analysis, we used RAxML v. 8 (Stamatakis 2014) and included 1,000 nonparametric bootstrap replicates. We used MrBayes for Bayesian inference analysis with ten million generations with a $25 \%$ burn-in and our support was assessed based on clade posterior probabilities (Ronquist and Huelsenbeck 2003). These analyses were conducted through CIPRES (Miller et al. 2010). We used PAUP* 4.0 (Swofford 2003) to construct parsimony phylogenies with 100 random additions. We performed the parsimony analysis twice, treating the deletions in the sequences as a $5^{\text {th }}$ state and then as missing data. We performed an uncorrected p-distance analysis to examine nucleotide differences between sequences with 1,000 replicates in MEGA7.0.18 (Kumar et al. 2016).

\section{Results}

Family Glossiphoniidae Vaillant, 1890

Genus Helobdella Blanchard, 1896

\section{Helobdella blinni sp. n.}

http://zoobank.org/B1B3D234-BC3F-4126-BF25-52DA00BA7EB9

Figs 2, 3, 4

Type materials. Holotype. USNM 1186106 (Table 2).

Additional materials. Paratypes. (14 specimens) (USNM 1186107, 1186108, 1186109, 1186110, 1186111, 1186112, 1186113, 1186114, 1186115, 1186116, 1186117, 1186118, 1186119, 1186120) (Table 2)

Type locality. USA, Arizona: Yavapai County, Montezuma Well $\left(34.6491^{\circ} \mathrm{N}\right.$, $\left.111.7522^{\circ} \mathrm{W}(\mathrm{DD})\right)$, aquatic system, under rocks, 10 June 2012, R.K. Beresic-Perrins.

Etymology. We have named this new species, Helobdella blinni in honor of Dr. Dean W. Blinn for his dedication to natural history research at Montezuma Well. For over 20 years at Northern Arizona University, Dr. Blinn studied a wide range of organisms and their interactions at Montezuma Well including predator-prey interactions between Motobdella montezuma and the endemic amphipod, Hyalella montezuma Cole \& Watkins, 1977.

Description. External morphology. Length of specimens 11 to $22 \mathrm{~mm}$ (mean + SE $16.6+3.2 \mathrm{~N}=24)$ and width 3 to $8 \mathrm{~mm}(5.7+1.1 \mathrm{~N}=28)$ (Table 3, Figs 2, 3). 

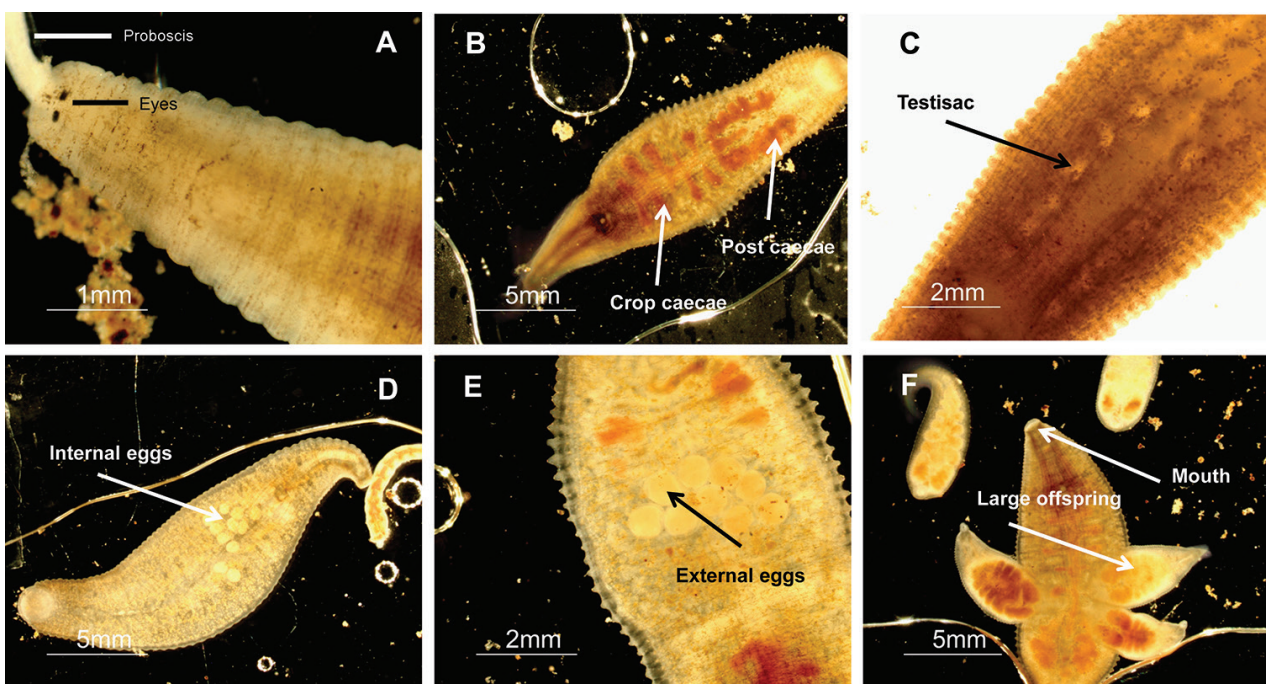

Figure 2. Internal and external morphology of Helobdella blinni sp. n. A dorsal view of the eyes and extended proboscis B crop and post caecae $\mathbf{C}$ testisacs $\mathbf{D}$ ventral view of internal eggs which have not been oviposited yet $\mathbf{E}$ ventral view of white eggs that have been oviposited $\mathbf{F}$ ventral view of attached and detached offspring.

Table 2. Holotype and paratype collection data and voucher numbers.

\begin{tabular}{|c|c|c|c|}
\hline Family & Species & Collection data & Voucher \# \\
\hline Glossiphoniidae & Helobdella blinni sp. n. & $\begin{array}{l}\text { USA: AZ: Yavapai Co., Montezuma Well } \\
34.6491^{\circ} \mathrm{N}, 111.7522^{\circ} \mathrm{W} \text { (DD), 10.VI.2010, } \\
\text { aquatic system, under rocks, RK Beresic- } \\
\text { Perrins, Holotype (USNM) }\end{array}$ & 1186106 \\
\hline \multirow{14}{*}{ Glossiphoniidae } & \multirow{14}{*}{ Helobdella blinni sp. n. } & \multirow{14}{*}{$\begin{array}{l}\text { (14 specimens) USA: AZ Yavapai Co., } \\
\text { Montezuma Well } 34.6491^{\circ} \mathrm{N}, 111.7522^{\circ} \mathrm{W} \\
\text { (DD), 10.VI.2010, aquatic system, under } \\
\text { rocks, RK Beresic-Perrins, Paratypes (USNM) }\end{array}$} & 1186107 \\
\hline & & & 1186108 \\
\hline & & & 1186109 \\
\hline & & & 1186110 \\
\hline & & & 1186111 \\
\hline & & & 1186112 \\
\hline & & & 1186113 \\
\hline & & & 1186114 \\
\hline & & & 1186115 \\
\hline & & & 1186116 \\
\hline & & & 1186117 \\
\hline & & & 1186118 \\
\hline & & & 1186119 \\
\hline & & & 1186120 \\
\hline
\end{tabular}

Individual color ranges from translucent with brown spots to dark brown (Fig. 4). No dorsal papillae; one pair of eyes located at somite II $(0.07+0.02 \mathrm{~mm}$ diameter, $\mathrm{N}=11)$, distance between eyes 0.1 to $0.03 \mathrm{~mm}$ apart $(\mathrm{N}=13)$. A scallop-shaped 

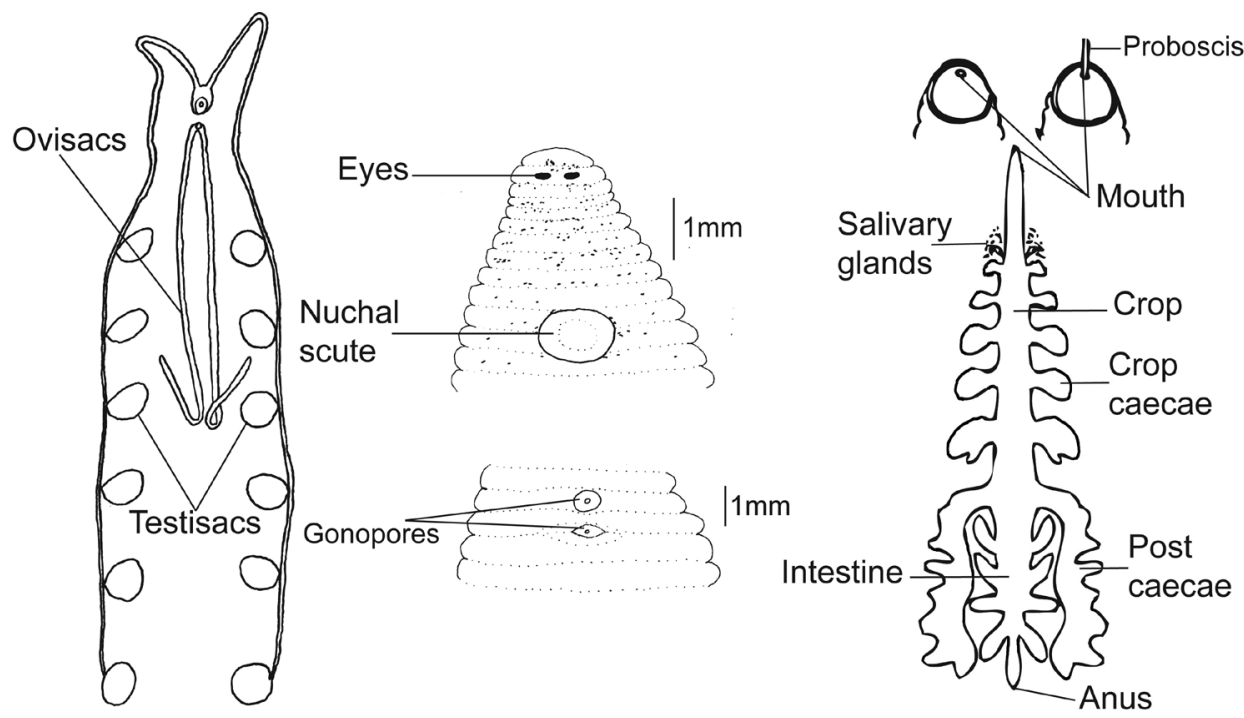

Figure 3. Diagram of the external and internal morphology of Helobdella blinni sp. n. (drawn by Rebecca Beresic-Perrins and Fredric Govedich).

Table 3. Morphological measurements of Helobdella blinni sp. n.

\begin{tabular}{l|c|c|c|c|c}
\hline \multicolumn{1}{c|}{ Trait } & Ave & SE & Min & Max & N \\
\hline body length relaxed $(\mathrm{mm})$ & 16.6 & 3.18 & 11.3 & 22.5 & 24 \\
\hline body width relaxed $(\mathrm{mm})$ & 5.7 & 1.15 & 3.1 & 8.0 & 28 \\
\hline caudal diameter $(\mathrm{mm})$ & 1.7 & 0.3 & 1.0 & 2.3 & 27 \\
\hline egg diameter $(\mathrm{mm})$ & 0.5 & 0.15 & 0.2 & 0.7 & 28 \\
\hline gonopore separation $(\mathrm{mm})$ & 0.1 & 0.08 & 0.1 & 0.3 & 13 \\
\hline nuchal scute length $(\mathrm{mm})$ & 0.335 & 0.05 & 0.284 & 0.432 & 9 \\
\hline nuchal scute width $(\mathrm{mm})$ & 0.32 & 0.04 & 0.27 & 0.386 & 9 \\
\hline proboscis length $(\mathrm{mm})$ & 3.5 & 1.10 & 2.0 & 6.2 & 17 \\
\hline oral sucker diameter $(\mathrm{mm})$ & 0.7 & 0.19 & 0.4 & 1.0 & 15 \\
\hline progeny length $(\mathrm{mm})$ & 3.6 & 1.68 & 1.6 & 6.6 & 18 \\
\hline progeny width $(\mathrm{mm})$ & 1.5 & 0.8 & 0.7 & 2.9 & 18 \\
\hline \# eggs & 10.0 & 2.73 & 7.0 & 16.0 & 7 \\
\hline \# progeny & 7.2 & 3.35 & 1.0 & 14.0 & 97 \\
\hline eye diameter $(\mathrm{mm})$ & 0.1 & 0.02 & 0.0 & 0.1 & 11 \\
\hline eye distance $(\mathrm{mm})$ & 0.1 & 0.04 & 0.0 & 0.2 & 13 \\
\hline
\end{tabular}

nuchal scute is present on the dorsal side, length 0.293 to $0.432 \mathrm{~mm}(0.335+0.05$ $\mathrm{N}=9)$ and width 0.27 to $0.386 \mathrm{~mm}(0.32+0.04 \mathrm{~N}=9)$. One annulus separates the female and male gonopores. The caudal sucker diameter averages $1.6+0.3 \mathrm{~mm}(\mathrm{~N}$ =27). The eggs (diameter $0.5+0.15 \mathrm{~mm}, \mathrm{~N}=28$ ) are laid on the ventral side of the parent in soft-walled transparent cocoons ( $7-11$ eggs per cocoon, $\mathrm{N}=7$ ). The mouth is located subterminally in the oral sucker (Figs 2, 3). 


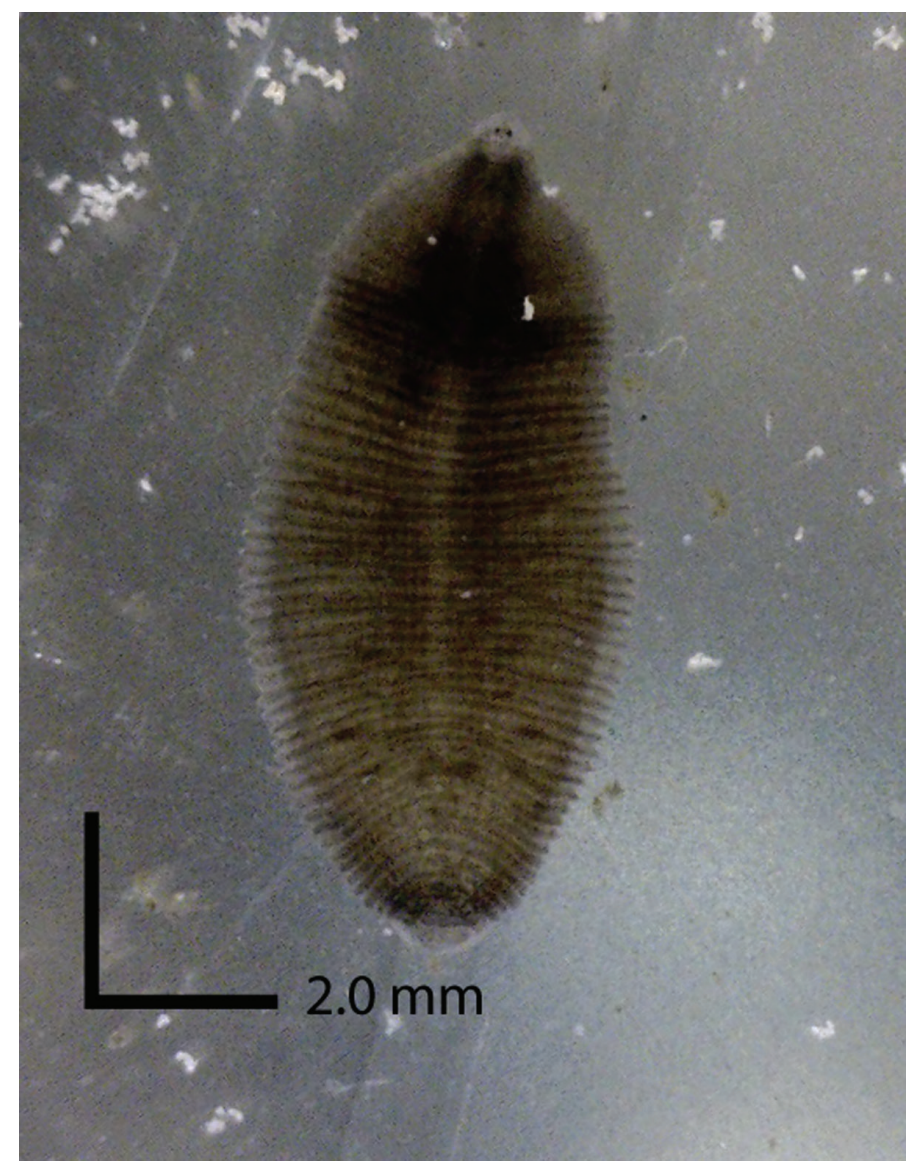

Figure 4. Typical pigmentation of Helobdella blinni sp. n.

Internal morphology. Average oral sucker diameter is $0.7+0.19 \mathrm{~mm}(\mathrm{~N}=15)$, proboscis length is $3.5+1.1 \mathrm{~mm}(\mathrm{~N}=17)$ (Table 3). Diffuse salivary glands are located near the anterior of the first pair of crop caecae. There are five pairs of smooth crop caecae and one lobed pair of posteriorly directed post caecae. Six pairs of compact testisacs are located in between each of the crop caecae. The intestine contains four pairs of caecae, with the first two pairs anteriorly directed and the other two pairs posteriorly directed. The intestine leads into an unraised anus located two annuli from the caudal sucker (Figure 3).

Development and growth. This species breeds year-round with peaks in spring and fall. Our specimens had an average of 7 to 11 white eggs (diameter $0.5+0.15$ $\mathrm{mm}, \mathrm{N}=7$ ) fixed to their ventral surface. Laboratory collections (2007-10) of $H$. blinni documented the eggs hatching 1 to 2 weeks after ovipositing (Beresic-Perrins 2010). Once hatched, the young attach to the ventral surface of the parent, allowing the parent to hunt for food and feed the young, occasionally feeding along with them. Prey consists of oligochaetes and other invertebrates. The average number of young per 
adult is $7+3.3(\mathrm{~N}=97)$ ranging from 1 to 14 offspring. The young remain attached to the parent for an additional four to five weeks after hatching. Once the juveniles leave the parent, they tend to aggregate together on rocks (Beresic-Perrins 2010).

\section{Molecular analysis}

A Bayesian inference phylogenetic tree of the COI sequence data is presented in Figure 5. We include the posterior probabilities and maximum-likelihood branch supports $>50$. The Arizona populations of Helobdella c.f. modesta formed a sister clade to Helobdella blinni sp. n., supported by both the Bayesian and parsimony analyses. The results of the uncorrected p-distance analysis revealed a difference of 13.3\% (233 nucleotides included) between the two groups (Table 6). The two groups form a larger clade with $H$. modesta (Ohio), H. stagnalis (UK), and $H$. modesta (Washington) which is supported by both Bayesian inference and maximum-likelihood. $H$. blinni differed from $H$. modesta (Ohio) by $13.7 \%, H$. stagnalis (UK) by $16.3 \%$, and $H$. modesta (Washington) by $16.3 \%$ (Table 6).

When we aligned all 78 sequences, there were four, ten-codon deletions within all of the Arizona sequences and H. atli (Oceguera-Figueroa and León-Regagnon 2005, Oceguera-Figueroa et al. 2010). When we performed the parsimony analysis, we included deletions as a $5^{\text {th }}$ state in our first analysis and in our second, we treated the deletions as missing data. In the resulting $5^{\text {th }}$ state tree, the two Arizona species remained sister taxa (100\% support), but included in the clade was $H$. atli (100\% and $58 \%$ support). The missing data tree placed $H$. blinni ancestral to $H$. modesta (Washington), $H$. modesta (Ohio), H. stagnalis (UK), and H. c.f. modesta with 100\% branch support (Fig. 5).

\section{Discussion}

Helobdella blinni sp. n. has morphological and life-history traits similar to other Helobdella species, including possession of a nuchal scute, diffuse salivary glands, six pairs of testisacs, and extended parental care for the young (6-7 weeks; Tables 4, 5). Helobdella blinni, H. bowermani (Moser et al. 2013), H. octatestisaca (Lai et al. 2009), and H. c.f. modesta each have five pairs of smooth crop caecae as opposed to six pairs of lobed crop caecae in H. californica (Kutschera 2011) and H. papillornata (Govedich and Davies 1998). Helobdella blinni and H. temiscoensis (Salas-Montiel et al. 2014) share pigmentation characteristics, but they differ internally. Helobdella temiscoensis has only four pairs of crop caecae and one descending post caecae as opposed to five pairs and one descending post caecae in H. blinni. Helobdella modesta, H. californica, H. atli, H. bowermani, and $H$. octatestisaca do not resemble the pigmentation of $H$. blinni, running the spectrum from grey to pink. Additionally, they have a descending pair of post caecae, whereas $H$. atli, $H$. californica, and $H$. papillornata do not. Helobdella blinni, 


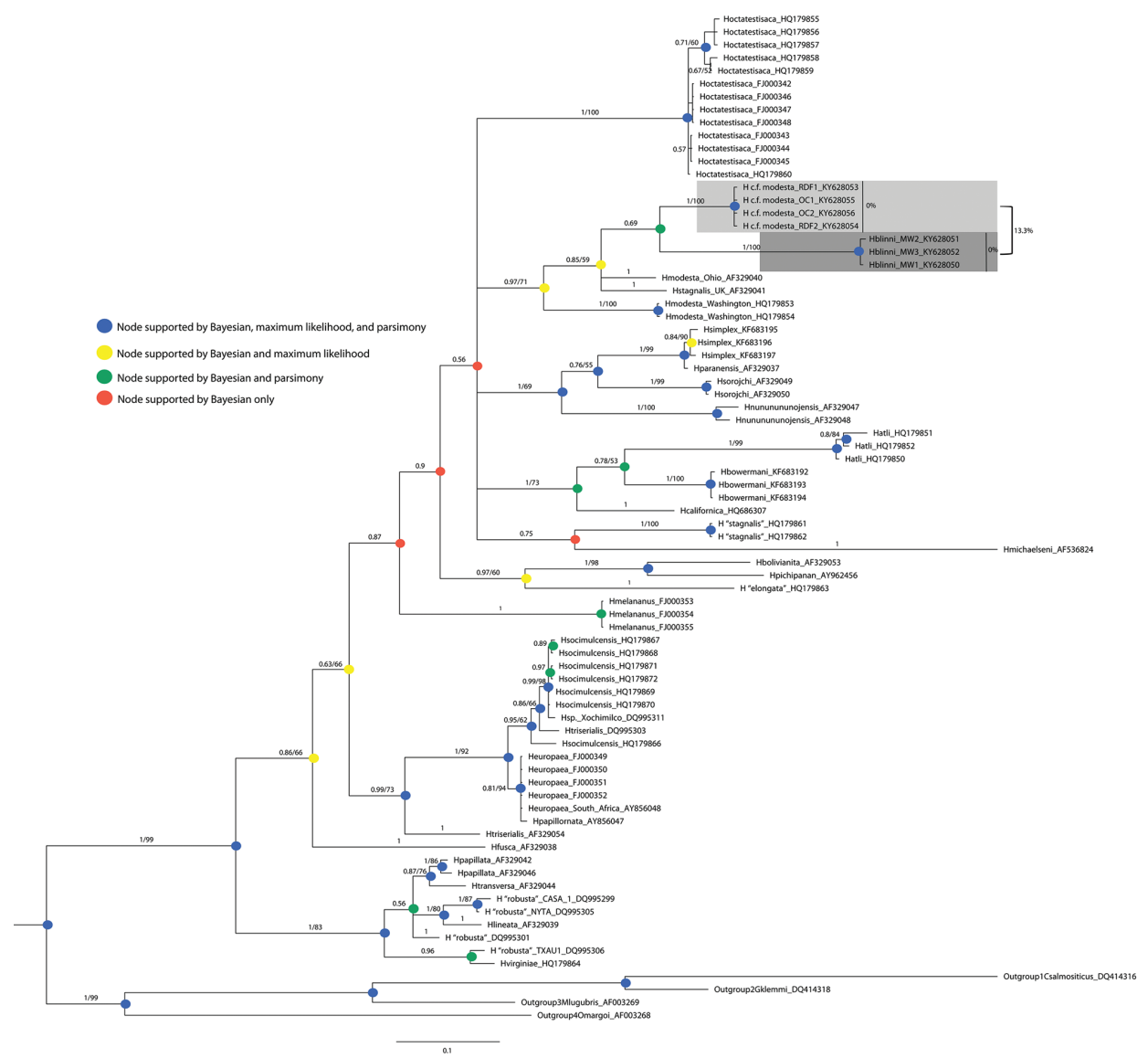

Figure 5. Bayesian Inference phylogenetic tree with 25\% burn-in and support was assessed based on clade posterior probabilities tree. We included COI sequences from 31 species of Helobdella (family Glossiphoniidae). The Arizona populations are from Oak Creek (OC), Rio de Flag (RDF), and Montezuma Well (MW). Our outgroup included Cystobranchus salmositicus (Meyer, 1946), Gonimosobdella klemmi (Williams \& Burreson, 2005), Myzobdella lugubris (Leidy, 1851), and Ozobranchus margoi (Davies, 1978). The shaded branches are the Arizona sample sequences. Branch labels include the Bayesian / ML probability. The blue nodes are supported by Bayesian Inference, Maximum-Likelihood, and parsimony analyses. The yellow nodes are supported by Bayesian Inference and Maximum-Likelihood analyses. The green nodes are supported by Bayesian Inference and parsimony analyses. The red nodes are supported by Bayesian Inference analysis only.

H. c.f. modesta, $H$. californica, $H$. temiscoensis, $H$. atli, and $H$. bowermani possess six pairs of testisacs, whereas $H$. papillornata has five pairs and $H$. octatestisaca has four pairs. Helobdella blinni also has a larger proboscis than the other Helobdella species (mean $+\mathrm{SE}, H$. blinni $3.5 \mathrm{~mm}+1.1, \mathrm{~N}=17$, H. californica mean $=0.7 \mathrm{~mm}, \mathrm{H}$. papillornata mean $=2 \mathrm{~mm}$ ). Furthermore, breeding periods also differ between $H$. blinni and the other Helobdella species (Tables 4, 5). 


\begin{tabular}{|c|c|c|c|c|c|c|c|c|c|c|c|c|c|c|c|}
\hline 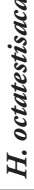 & 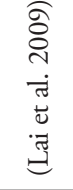 & 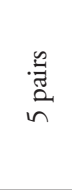 & $\mid$ & 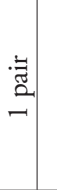 & $n$. & $\stackrel{Z}{Z}$ & 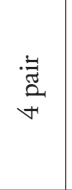 & 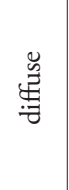 & $n$. & 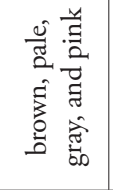 & $\mid \begin{array}{c}z \\
z \\
\vdots \\
\pm \\
1 \\
\alpha \\
\sigma\end{array}$ & 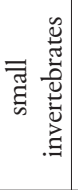 & $n$. & $n$. & $n \cdot n$ \\
\hline 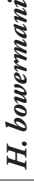 & 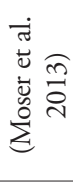 & 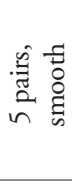 & $\begin{array}{c}\text {.ี } \\
2 \\
-1\end{array}$ & 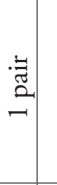 & $n$. & $\stackrel{2}{Z}$ & 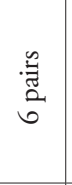 & 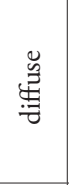 & $n$. & 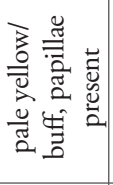 & 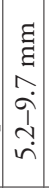 & n. & n. & n. & $\sim \cdot n$ \\
\hline 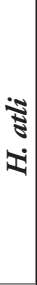 & 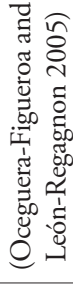 & 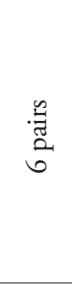 & 节. & م. & $n$. & 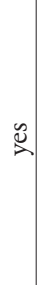 & 䒕 & $n$. & $n$. & 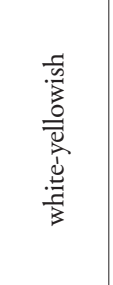 & $\mid \begin{array}{c}\xi \\
\vdots \\
n \\
\sim \\
\end{array}$ & n. & $n$. & $n$. & $n \cdot \Omega$ \\
\hline 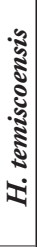 & 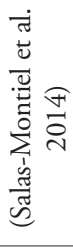 & 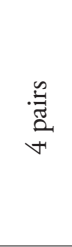 & 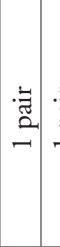 & 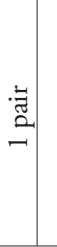 & $n$. & $\mathscr{Z}$ & .气ีّี & $\stackrel{\mathscr{ٌ}}{\dddot{G}}$ & $n$. & 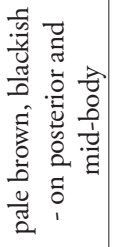 & $\mid \begin{array}{c}z \\
\vdots \\
\vdots \\
\dot{n} \\
\vdots \\
\vdots \\
\grave{r}\end{array}$ & $n$ & n. & $n$ & $n \cdot \mid r$ \\
\hline 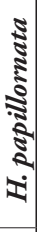 & 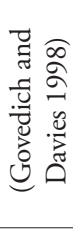 & 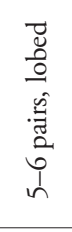 & : & 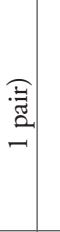 & 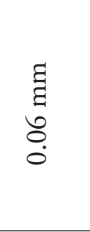 & $\stackrel{9}{g}$ & 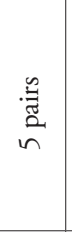 & 苞 & हี & 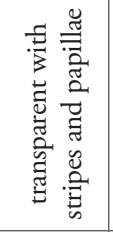 & $\mid \begin{array}{c}z \\
z \\
\vdots \\
o \\
+ \\
n \\
n\end{array}$ & 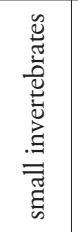 & $\begin{array}{l}\tilde{u} \\
\ddot{\tilde{u}} \\
\vdots \\
0 \\
\forall\end{array}$ & . & 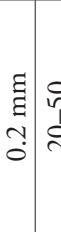 \\
\hline 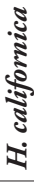 & 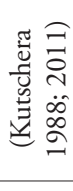 & 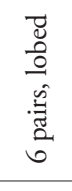 & 号. & ב. & $n$. & $\stackrel{\mathscr{Z}}{\mathscr{Z}}$ & $\frac{\text { हैँ }}{2}$ & $n$. & $\begin{array}{l}\tilde{\Xi} \\
\stackrel{\Xi}{0} \\
0\end{array}$ & 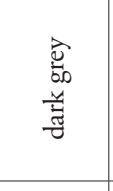 & $\mid \begin{array}{c}z \\
\vdots \\
\infty \\
\infty \\
\vdots \\
0 \\
\end{array}$ & 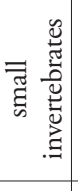 & 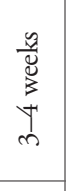 & $\frac{-4}{\Xi}$ & 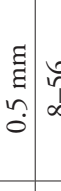 \\
\hline 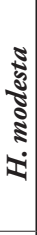 & 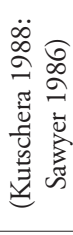 & 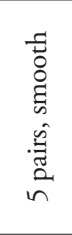 & 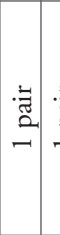 & בै & $n$. & 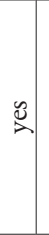 & .气 & $\stackrel{\mathscr{g}}{\stackrel{⿹}{ت}}$ & n. & 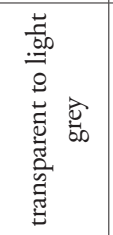 & 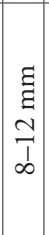 & 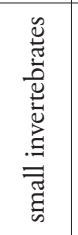 & $\begin{array}{c}\frac{\tilde{u}}{\tilde{\Xi}} \\
\vdots \\
\hat{3}\end{array}$ & 咅 & r. \\
\hline 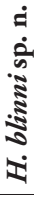 & 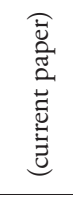 & 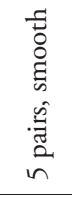 & 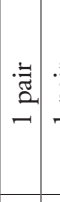 & 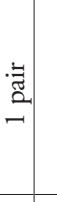 & $\begin{array}{c}E \\
\text { E } \\
\stackrel{-}{0}\end{array}$ & 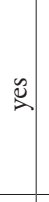 & .气ีّี & 岂 & $\begin{array}{l}\text { हี } \\
\text { ڤે } \\
\text { ஸे }\end{array}$ & 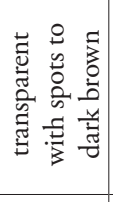 & 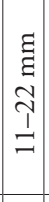 & 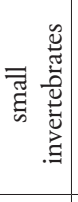 & $\begin{array}{c}\frac{\tilde{u}}{\tilde{u}} \\
\vdots \\
\hat{\jmath}\end{array}$ & $\frac{2}{\frac{2}{3}}$ & 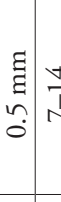 \\
\hline औีํㄴ & & 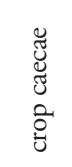 & 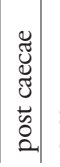 & ठั. & 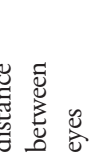 & 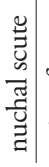 & 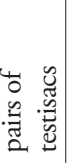 & 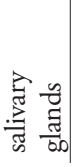 & 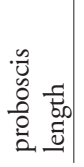 & $\frac{\overline{0}}{8}$ & 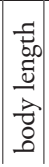 & 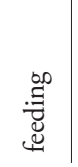 & 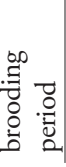 & $\left|\begin{array}{l|}0 \\
0 \\
0 \\
0 \\
60 \\
00 \\
0\end{array}\right|$ & 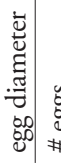 \\
\hline
\end{tabular}


Table 5. Differences in brooding season and size between $H$. blinni sp. n., H. stagnalis, and $H$. c.f. modesta.

\begin{tabular}{|c|c|c|c|}
\hline Location & Brooding Season & $\begin{array}{c}\text { Average \# of } \\
\text { offspring }\end{array}$ & Author \\
\hline $\begin{array}{l}\text { H. blinni sp. n. } \\
\text { Montezuma Well, AZ }\end{array}$ & Year-round & $1-14$ & Beresic-Perrins (2010) \\
\hline $\begin{array}{l}\text { H. modesta } \\
\text { Utah Lake, UT }\end{array}$ & Late spring through summer & $12.6-17.4$ & Tillman and Barnes (1973) \\
\hline $\begin{array}{l}\text { H. modesta } \\
\text { Lake Washington, WA }\end{array}$ & Spring and Summer & 14.5 & Thut (1969) \\
\hline $\begin{array}{l}\text { H. modesta } \\
\text { Marion Lake, BC, CA }\end{array}$ & Spring and Summer & $17.2-19.7$ & \multirow{2}{*}{$\begin{array}{l}\text { Davies and Reynoldson } \\
\text { (1976) }\end{array}$} \\
\hline $\begin{array}{l}\text { H. modesta } \\
\text { Newsome Pond, AB, CA }\end{array}$ & Late spring through summer & 21.3 & \\
\hline $\begin{array}{l}\text { H. modesta } \\
\text { Cambridge, MA }\end{array}$ & Spring & 31 & Castle (1900) \\
\hline $\begin{array}{l}\text { H. modesta } \\
\text { Michigan }\end{array}$ & Late spring through summer & 35.3 & Sawyer (1972) \\
\hline $\begin{array}{l}\text { H. stagnalis } \\
\text { Iceland }\end{array}$ & Late spring through summer & No data & Bruun (1938) \\
\hline $\begin{array}{l}\text { H. stagnalis } \\
\text { River Ely, South Wales }\end{array}$ & Late spring through summer & No data & Murphy and Learner (1982) \\
\hline $\begin{array}{l}\text { H. stagnalis } \\
\text { Whiteknights Lake, UK }\end{array}$ & Late spring through summer & $13-17$ & Mann (1957) \\
\hline $\begin{array}{l}\text { H. stagnalis } \\
\text { Eglwys Nunydd, UK }\end{array}$ & Late spring through summer & 14 & Learner and Potter (1974) \\
\hline $\begin{array}{l}\text { H. stagnalis } \\
\text { Denmark }\end{array}$ & Late spring through summer & 20 & Bennike (1943) \\
\hline
\end{tabular}

Helobdella blinni, unlike the other Helobdella species discussed here, breeds yearround, living in the thermally stable environment of Montezuma Well, with constant $\left(19-24^{\circ} \mathrm{C}\right)$ year-round temperatures (Table 5). Monthly samples have individuals carrying cocoons every month of the year, with peak seasons in the spring and fall, a situation quite different than that for other Helobdella species, which have seasonallyconstrained reproductive cycles, with egg-laying and brooding beginning in the spring and ending in the fall every year (Table 5). In addition to breeding year-round, $H$. blinni produces smaller broods (7-14 young) when compared to $H$. modesta and $H$. stagnalis $(12-35$ young) (Tables 4,5$)$ and has white eggs, unlike the characteristically pink eggs of $H$. modesta, $H$. californica, and $H$. papillornata (Table 4). The external pigmentation of $H$. blinni also tends to be dark brown, whereas most other Helobdella species are grey/brown in color (Fig. 4). Helobdella blinni are slightly longer (body length $11-22 \mathrm{~mm}, 16.6+3.2, \mathrm{~N}=24)$ than $H$. c.f. modesta $(8-12 \mathrm{~mm})$ and $H$. californica $(10-18 \mathrm{~mm})$, but slightly shorter in length than $H$. papillornata $(15-40 \mathrm{~mm})$ (Table 4).

The results from our molecular analysis show $H$. blinni to be genetically distinct from other Helobdella species, both from the same region (Rio de Flag and Oak Creek, 
Table 6. Uncorrected p-distance pairwise analysis.

\begin{tabular}{|c|c|c|}
\hline Species & Distance - H. blinni & Distance - $H$. c.f. modesta \\
\hline H. atli & $14.1-15 \%$ & $16.7 \%$ \\
\hline H. bolivianita & $18.5 \%$ & $19.3 \%$ \\
\hline H. bowermani & $15.9 \%$ & $15.5 \%$ \\
\hline H. blinni & $0.0 \%$ & $13.3 \%$ \\
\hline H. californica & $16.7 \%$ & $17.6 \%$ \\
\hline$H$. c.f. modesta & $13.3 \%$ & $0.0 \%$ \\
\hline H. elongata & $18.0 \%$ & $19.3 \%$ \\
\hline H. europaea & $15.5 \%$ & $16.3 \%$ \\
\hline H. fusca & $19.3 \%$ & $20.6 \%$ \\
\hline H. lineata & $16.3 \%$ & $14.6 \%$ \\
\hline H. melananus & $16.3 \%$ & $17.2 \%$ \\
\hline H. michaelseni & $23.2 \%$ & $20.6 \%$ \\
\hline H. modesta $\mathrm{OH}$ & $13.7 \%$ & $8.6 \%$ \\
\hline H. modesta WA & $16.3 \%$ & $14.6 \%$ \\
\hline H. nununununojensis & $17.5-19 \%$ & $17.5-19.7 \%$ \\
\hline H. octatestisaca & $19.7 \%$ & $16.3 \%$ \\
\hline H. papillata & $17.6 \%$ & $15.8-16.3 \%$ \\
\hline H. papillornata & $15.9 \%$ & $16.7 \%$ \\
\hline H. paranensis & $16.3 \%$ & $13.7 \%$ \\
\hline H. pichipanan & $17.2 \%$ & $19.3 \%$ \\
\hline H. robusta & $17.6 \%$ & $14.6 \%$ \\
\hline H. aff robusta CASA & $18.9 \%$ & $17.2 \%$ \\
\hline H. aff robusta NYTA & $17.6 \%$ & $15.9 \%$ \\
\hline H. aff robusta TXAU1 & $17.2 \%$ & $18.0 \%$ \\
\hline H. simplex & $16.3 \%$ & $13.7-14.2 \%$ \\
\hline H. socimulcensis & $15.9 \%$ & $16.7-17.2 \%$ \\
\hline H. sorojchi & $18-18.5 \%$ & $17.6 \%$ \\
\hline H. sp. Xochimilco & $15.5 \%$ & $17.2 \%$ \\
\hline H. stagnalis & $20.6 \%$ & $17.2 \%$ \\
\hline H. stagnalis $U K$ & $16.3 \%$ & $11.6 \%$ \\
\hline H. transversa & $16.3 \%$ & $15.0 \%$ \\
\hline H. triserialis & $15.9 \%$ & $16.7-18.5 \%$ \\
\hline H. virginiae & $16.3 \%$ & $16.7 \%$ \\
\hline Outgroup1 C. salmositicus & $24.9 \%$ & $23.2 \%$ \\
\hline Outgroup2 G. klemmi & $21.5 \%$ & $21.5 \%$ \\
\hline Outgroup3 M. lugubris & $18.0 \%$ & $19.3 \%$ \\
\hline Outgroup4 O. margoi & $23.2 \%$ & $20.2 \%$ \\
\hline
\end{tabular}

Arizona populations) and from Europe (UK sample). The sequences yielded a 13.3\%$17.4 \%$ genetic difference between $H$. blinni and both the Arizona $H$. c.f. modesta, $H$. modesta (Ohio and Washington), and the United Kingdom H. stagnalis populations (Table 6). The three Arizona populations belong to their own separate clade, but are closely related to $H$. stagnalis (UK) and the $H$. modesta. Helobdella atli, $H$. bowermani, 
and $H$. californica are located on separate branch tips, but they comprise what OcegueraFigueroa et al. (2010) designated as the "stagnalis" series (Fig. 5).

Based on morphological, life-history, and molecular differences, we propose the Helobdella sp. leeches found at Montezuma Well should be considered a new species, likely the result of allopatric isolation. This concept supports our hypothesis that the leech species inhabiting Montezuma Well may have become isolated from other populations as far back as 11,000 years ago (Wagner and Blinn 1987). Helobdella blinni sp. n. can be considered a distinct species found in Montezuma Well and may also turn out to be endemic to the area. Further sampling and analyses are needed in order to verify endemism.

Although currently classified as Helobdella c.f. modesta, the Arizona populations from the Rio de Flag and Oak Creek may be an additional undescribed species based on our molecular analysis. Our next step is to investigate these populations more closely, comparing them to other local populations, including White Horse Lake and J.D. Dam Lake, AZ which also contain $H$. modesta.

\section{Acknowledgements}

We would like to thank the National Park Service rangers and volunteers at the Montezuma Castle National Monument, especially Rex Vanderford, who assisted with collections and permits. Funding for the molecular and morphological analyses was provided by the National Science Foundation's Integrative Graduate Education and Research Traineeship. William Moser, Smithsonian Institution, National Museum of Natural History, Department of Invertebrate Zoology, provided valuable assistance in specimen management. Dr. Tina Ayers and Tamara Max (Northern Arizona University, Department of Biological Sciences) provided valuable assistance and insight with molecular data analyses. All the members past and present of Dr. Stephen Shuster's laboratory were indispensable with all aspects of data collection for this manuscript.

\section{References}

Apakupakul K, Siddall ME, Burreson EM (1999) Higher level relationships of leeches (Annelida: Clitellata: Euhirudinea) based on morphology and gene sequences. Molecular Phylogenetics and Evolution 12: 350-359. https://doi.org/10.1006/mpev.1999.0639

Bennike SAB (1943) Contributions to the ecology and biology of the Danish freshwater leeches (Hirudinea). Folia Limnologica Scandinavica 2: 1-109.

Beresic-Perrins RK (2010) The life-history and parental care in an Arizona population of Helobdella stagnalis (Hirudinea: Glossiphoniidae). Master's thesis, Flagstaff, Arizona: Northern Arizona University.

Bely AE, Weisblat DA (2006) Lessons from leeches: a call for DNA barcoding in the lab. Evolution \& Development 8: 491-501. https://doi.org/10.1111/j.1525-142X.2006.00122.x 
Blanchard R (1896) Viaggio del Dott. A. Borellinella Republica Argentina e nel Paraguay. 21. Hirudine'es. Bollettino dei Musei di Zoologia ed. Anatomia comparata Universita di Torino 11: 1-24.

Bruun AF (1938) Freshwater Hirudinea. Zoology Iceland 2: 22.

Castle RE (1900) Some North American fresh-water Rhynchobdellida, and their parasites. Bulletin of the Museum of Comparative Zoology 36: 39-42.

Cole GA, Barry WT (1973) Montezuma Well, Arizona, as a habitat. Journal of the Arizona Academy of Sciences 8: 7-13. https://doi.org/10.2307/40022206

Cole GA, Watkins RL (1977) Hyalella montezuma, a new species (Crustacea: Amphipoda) from Montezuma Well, Arizona. Hydrobiologia 52:175-184. https://doi.org/10.1007/ BF00036441

Davies RW, Reynoldson TB (1976) A comparison of the life cycle of Helobdella stagnalis (Linn. 1758) (Hirudinoidea) in two different geographical areas. Canadian Journal of Animal Ecology 45: 457-470. https://doi.org/10.2307/3885

Davies R (1978) The morphology of Ozobranchus margoi (Apathy) (Hirudinoidea), a parasite of marine turtles. The Journal of Parasitology 64: 1092-1096. https://doi.org/10.2307/3279733

Davies RW, Singhal RN, Blinn DW (1985) Erpobdella montezuma (Hirudinoidea: Erpobdellidae), a new species of freshwater leech from North America. Canadian Journal of Zoology 63: 965-969. https://doi.org/10.1139/z85-142

Edgar RC (2004) MUSCLE: multiple sequence alignment with high accuracy and high throughput. Nucleic Acids Research 32: 1792-1797. https://doi.org/10.1093/nar/gkh340

Folmer O, Black M, Hoeh W, Lutz R, Vrijenhoek R (1994) DNA primers for amplification of mitochondrial cytochrome $C$ oxidase subunit I from diverse metazoan invertebrates. Molecular Marine Biology and Biotechnology 3: 294-299.

Govedich FR, Blinn DW, Keim P, Davies RW (1998) Phylogenetic relationships of three genera of Erpobdellidae (Hirudinoidea), with a description of a new genus, Motobdella, and species, Motobdella sedonensis. Canadian Journal of Zoology 76: 2164-2171. https:/doi. org/10.1139/z98-132

Govedich FR, Davies RW (1998) The first record of the genus Helobdella (Hirudinoidea: Glossiphoniidae) from Australia, with a description of a new species, Helobdella papillornata. Hydrobiologia 389: 45-49. https://doi.org/10.1023/A:1003543314841

Kumar S, Stecher G, Tamura K (2016) MEGA7: Molecular Evolutionary Genetics Analysis version 7.0 for bigger datasets. Molecular Biology and Evolution 33: 1870-1874. https:// doi.org/10.1093/molbev/msw054

Kutschera U (1988) A new leech species from North America, Helobdella californica nov. sp. (Hirudinea: Glossiphoniidae). Zoologischer Anzeiger 220: 173-178.

Kutschera U (2011) The Golden Gate leech Helobdella californica nov. sp. (Hirudinea: Glossiphoniidae): occurrence and DNA-based taxonomy of a species restricted to San Francisco. International review of Hydrobiology 96: 286-295. https://doi.org/10.1002/iroh.201111311

Lai Y-T, Chang C-H, Chen J-H (2009) Two new species of Helobdella Blanchard 1896 (Hirudinida: Rhynchobdellida: Glossiphoniidae) from Taiwan, with a checklist of hirudinea fauna of the island. Zootaxa 2068: 27-46. 
Lanave C, Preparata G, Sacone C, Serio G (1984) A new method for calculating evolutionary substitution rates. Journal of Molecular Evolution 20: 86-93. https://doi.org/10.1007/ BF02101990

Lanfear R, Calcott B, Ho SY, Guindon S (2012) PartitionFinder: combined selection of partitioning schemes and substitution models for phylogenetic analyses. Molecular Biology and Evolution 29: 1695-701. https://doi.org/10.1093/molbev/mss020

Learner MA, Potter DWB (1974) Life history and production of the leech Helobdella stagnalis (L.) (Hirudinea) in a shallow eutrophic reservoir in South Wales. Journal of Animal Ecology 43: 199-208. https://doi.org/10.2307/3167

Leidy J (1851) Gen. nov. Myzobdella. Proceedings of the Academy of Natural Sciences of Philadelphia 5: 243.

Linnaeus C (1758) Systema naturae per regna tria naturae, secundum classes, ordines, genera, species, cum characteribus, differentiis, synonymis, locis. Tomus I. Editio Decima. Holmiae, Laurentii Salvii.

Mann KH (1957) The breeding, growth and age structure of a population of the leech Helobdella stagnalis (L.). Journal of Animal Ecology 26: 171-177. https://doi.org/10.2307/1787

Meyer M (1946) Further Notes on the leeches (Piscicolidae) living on fresh-water fishes of North America. Transactions of the American Microscopical Society 65: 237-249. https:// doi.org/10.2307/3223419

Miller MA, Pfeiffer W, Schwartz T (2010) Creating the CIPRES Science Gateway for inference of large phylogenetic trees. In: Proceedings of the Gateway Computing Environments Workshop (GCE), New Orleans, LA, 1-8. https://doi.org/10.1109/gce.2010.5676129

Moore JP (1898) Leeches of the United States National Museum. Proceedings of the U.S. National Museum 21: 543-563. https://doi.org/10.5479/si.00963801.21-1160.543

Moore JP (1952) Professor A.E. Verrill's freshwater leeches - a tribute and critique. Notulae Naturae of the Academy of Natural Sciences of Philadelphia 245: 1-15.

Moser WE, Klemm DJ, Richardson DJ, Wheeler BA, Trauth SE, Daniels BA (2006) Leeches (Annelida: Hirudinida) of northern Arkansas. Journal of the Arkansas Academy of Science 60: 84-95.

Moser WE, Richardson DJ, Hammond CI, Lazo-Wasem E (2011) Molecular characterization of Helobdella modesta (Verrill, 1872) (Hirudinida: Glossiphoniidae) from its type locality, West River and Whitneyville Lake, New Haven County, Connecticut, USA. Zootaxa 2834: 65-68.

Moser WE, Fend SV, Richardson DJ, Hammond CI, Lazo-Wasem EA, Govedich FR, Gullo BS (2013) A new species of Helobdella (Hirudinida: Glossiphoniidae) from Oregon, USA. Zootaxa 3718: 287-94. https://doi.org/10.11646/zootaxa.3718.3.5

Murphy PM, Learner MA (1982) The life history and reproduction of the leech Helobdella stagnalis (Hirudinea: Glossiphonidae) in the River Ely, South Wales. Freshwater Biology 12: 321-329. https://doi.org/10.1111/j.1365-2427.1982.tb00626.x

Oceguera-Figueroa A, León-Regagnon V (2005) A new freshwater leech species of Helobdella (Annelida: Glossiphoniidae) from central Mexico. Zootaxa 976: 1-8. https://doi. org/10.11646/zootaxa.976.1.1 
Oceguera-Figueroa A, León-Règagnon V, Siddall ME (2010) DNA barcoding reveals Mexican diversity within the freshwater leech genus Helobdella (Annelida: Glossiphoniidae). Mitochondrial DNA 21: 24-9. https://doi.org/10.3109/19401736.2010.527965

Rodriguez FJ, Oliver JL, Marin A, Medina JR (1990) The general stochastic model of nucleotide substitution. Journal of Theoretical Biology 142: 485-501. https://doi.org/10.1016/ S0022-5193(05)80104-3

Ronquist F, Huelsenbeck JP (2003) MrBayes 3: Bayesian phylogenetic inference under mixed models. Bioinformatics 19: 1572-1574. https://doi.org/10.1093/bioinformatics/btg180

Salas-Montiel R, Phillips AJ, De Leon GP, Oceguera-Figueroa A (2014) Description of a new leech species of Helobdella (Clitellata: Glossiphoniidae) from Mexico with a review of Mexican congeners and a taxonomic key. Zootaxa 3900: 77-94. https://doi.org/10.11646/ zootaxa.3900.1.4

Sawyer RT (1972) North American freshwater leeches, exclusive of the Piscicolidae, with a key to all species. Illinois Biological Monographs, Univ. of Illinois Press, Urbana. https://doi. org/10.5962/bhl.title.53881

Sawyer RT (1986) Leech Biology and Behaviour, Vols. I-III. Clarendon Press, Oxford, United Kingdom, 1065 pp.

Siddall ME, Burreson EM (1998) Phylogeny of leeches (Hirudinea) based on mitochondrial cytochrome $c$ oxidase subunit I. Molecular Phylogenetics and Evolution 9: 156-62. https:// doi.org/10.1006/mpev.1997.0455

Siddall ME, Borda E (2002) Phylogeny and revision of the leech genus Helobdella (Glossiphoniidae) based on mitochondrial gene sequences and morphological data and a special consideration of the triserialis complex. Zoologica Scripta 32: 23-33. https://doi.org/10.1046/ j.1463-6409.2003.00098.x

Siddall ME, Budinoff RB (2005) DNA-barcoding evidence for widespread introductions of a leech from the South American Helobdella triserialis complex. Conservation Genetics 6: 467-72. https://doi.org/10.1007/s10592-005-4986-y

Siddall ME, Budinoff RB, Borda E (2005) Phylogenetic evaluation of systematics and biogeography of the leech family Glossiphoniidae. Invertebrate Systematics 19: 105-112. https:// doi.org/10.1071/IS04034

Stamatakis A (2014) RAxML Version 8: A tool for phylogenetic analysis and post-analysis of large phylogenies. Bioinformatics 30: 1312-1313. https://doi.org/10.1093/bioinformatics/btu033

Swofford DL (2003) PAUP* Version 4. Phylogenetic analysis using parsimony ("and other methods).

Tavare S (1986) Some probabilistic and statistical problems on the analysis of DNA sequences. In: Lectures in mathematics in the life sciences, vol. 17, 57-86.

Thut RN (1969) A study of the profundal bottom fauna of Lake Washington. Ecological Monographs 39: 79-100. https://doi.org/10.2307/1948566

Tillman DL, Barnes JR (1973) The reproductive biology of the leech Helobdella stagnalis (L.) in Utah Lake, Utah. Freshwater Biology 3: 137-145. https://doi.org/10.1111/j.1365-2427.1973.tb00068.x 
Vaillant L (1890) Histoire naturelle des Anneles marin et d'eau douce. 3/2, Ordre Hirudiens (Hirudines) ou Bdelles, Paris, 477-542.

Verrill AE (1872) Descriptions of North American freshwater leeches. American Journal of Science and Arts 3:126-139. https://doi.org/10.2475/ajs.s3-3.14.126

Wagner VT, Blinn DW (1987) Montezuma Well: the living desert oasis. http://www.nps.gov/ history/history/online_books/moca/montezuma_well/index.htm

Williams JI, Burreson EM (2005) Gonimosobdella klemmi n. gen., n. sp. (Hirudinida: Piscicolidae) from cyprinid fishes in Arkansas, Illinois, and Missouri, USA. Comparative Parasitology 72: 166-72. https://doi.org/10.1654/4180

Williams JI, Burreson EM (2006) Phylogeny of the fish leeches (Oligochaeta, Hirudinida, Piscicolidae) based on nuclear and mitochondrial genes and morphology. Zoologica Scripta 35: 627-639. https://doi.org/10.1111/j.1463-6409.2006.00246.x 